\title{
Tisztelettel adóztak az anyák megmentőjének - 2017. évi Semmelweis ünnepség, Győr-Sziget
}

\author{
Salutations to Mothers' Savior - 2017 Semmelweis Ceremony, Győr-Sziget
}

\author{
Szerző: Schmidt Péter $\bowtie$ \\ Egyetemi Oktató Gyermekorvosi Rendelő, Győr
}

Beküldve: 2017.08.10.

doi: $10.24365 /$ ef.v58i3.172

Kulcsszavak: prevenció, gyermekágyi láz, klórvizes kézmosás, Semmelweis Emlékév, márvány emléktábla és koszorúzás (Semmelweis tiszteletére)

Keywords: prevention, puerperal fever, washing hands with chlorinated water, Semmelweis Memorial Year, marble plaque and wreaths (in honour of Semmelweis)

1818. július elseje a magyar, de a világ egészségügyének egyik legkiemelkedőbb napja: ekkor született Budán az ottani fúszeres gyermekeként Semmelweis Ignác Fülöp, orvos -tudós, akit a világ 10 legkiválóbb orvosaként tartanak számon. ${ }^{1}$ Szülei hadbírónak szánták, de ő ragaszkodott elveihez, a gyógyítást választotta élethivatásául. Egyetemi tanulmányait és élete nagy részét Bécsben töltötte, de számos európai országban is megfordult, kutatásait és tanait hirdetve.

Az osztrák főváros szülészeti klinikáján dolgozta ki a világraszóló találmányt, amely mai szemmel egyszerúnek tűnik: a klórvizes kézmosást. Az általa vezetett bécsi szülészeti klinikán kötelezővé tette a boncteremből a szülőszobába érkező orvosoknak és medikusoknak a klórvizes kézmosást, így minimálisra csökkent az anyai halálozás, míg a klórvizes kézmosást nem alkalmazó másik szülészeten tombolt a gyermekágyi láz, az anyai halálozás igen magas volt. $^{1,2}$

Életében ugyan nem, de halála utáni évtizedekben Szentpétervártól Londonig, Ausztráliától az Egyesült Államokig ismertté vált a neve, s számos nyelven publikálták könyvét a "gyermekágyi lázról”. Semmelweis életében nem élvezhette világraszóló eredményeit. Nemcsak Bécsben, de később Pestre kerülve is igen sok irigye volt, tanait csak jóval halála után ismerték el világszerte, pedig ez a viszonylag egyszerűnek tűnő felfedezés sok százezer anya és újszülött életét mentette meg, illetve menti meg ma is. ${ }^{1}$

Mi magyarok büszkék lehetünk rá, nevét utcák, terek, kórházak és klinikák viselik. 2015-ben - halála 150. évfordulóján - Semmelweis Emlékévet hirdettek meg a világon, melynek egyik legfontosabb eseménye volt, hogy Chicagóban, a világ leghíresebb orvosainak Pantheonjában szobrot állítottak Semmelweis Ignác Fülöp tiszteletére. ${ }^{3,4}$

Győr városa a rendszerváltást követően hagyományos módon adózik Semmelweisi Ignác Fülöp emlékének. ${ }^{2,5}$ A 2017. évi központi ünnepségnek GyőrSzigetben az Egyetemi Oktató Gyermekorvosi Rendelő szolgált helyszínéül. Radnóti Ákos, Győr város alpolgármestere kiemelte Győr-Sziget Semmelweis kezdeményezésének fontosságát, egyben Borkai Zsolt polgármester úr nevében elismerő oklevelet nyújtott át Dr. Györkös Zoltán és Dr. Schneider Károly nyugalmazott főorvosoknak, akik az ünnepség keretében beszámoltak több évtizedes gyógyító munkájukról. 
Dr. Györkös Zoltán a győri Petz Aladár Megyei Oktató Kórház Higiénés Részlege Osztályvezető főorvosaként egész életét a kórházi fertőzések megelőzésére tette fel. A komoly szakmai elvárásoknak évtizedeken keresztül kiválóan megfelelt, míg Dr. Schneider Károly a Győr-Moson Sopron megyei Osli település körzeti orvosaként napi gyógyító munkája mellett egészségnevelőként is tevékenykedett, egészségfejlesztésben és annak képzésében jeles- kedett. Nyugdíjas éveiben is állandóan képezi magát, a győri Alapellátási Szabadegyetem állandó résztvevőjeként üléselnök és előadó.

Az ünnepség zárásaként megkoszorúzták a rendelő falán 2000. július 1-én felállított Semmelweis márvány emléktáblát, ahol Radnóti Ákos és Dr. Schmidt Péter, valamint az ünnepeltek, Dr. Györkös Zoltán és Dr. Schneider Károly, illetve Dr. Nagyné Oross Ilona és Korompáky Mária Valéria koszorúzott. 5,6

1. ábra: Radnóti Ákos, Györ város alpolgármestere adja át az elismeréseket Dr. Györkös Zoltán és Dr. Schneider Károly nyugalmazott föorvosoknak

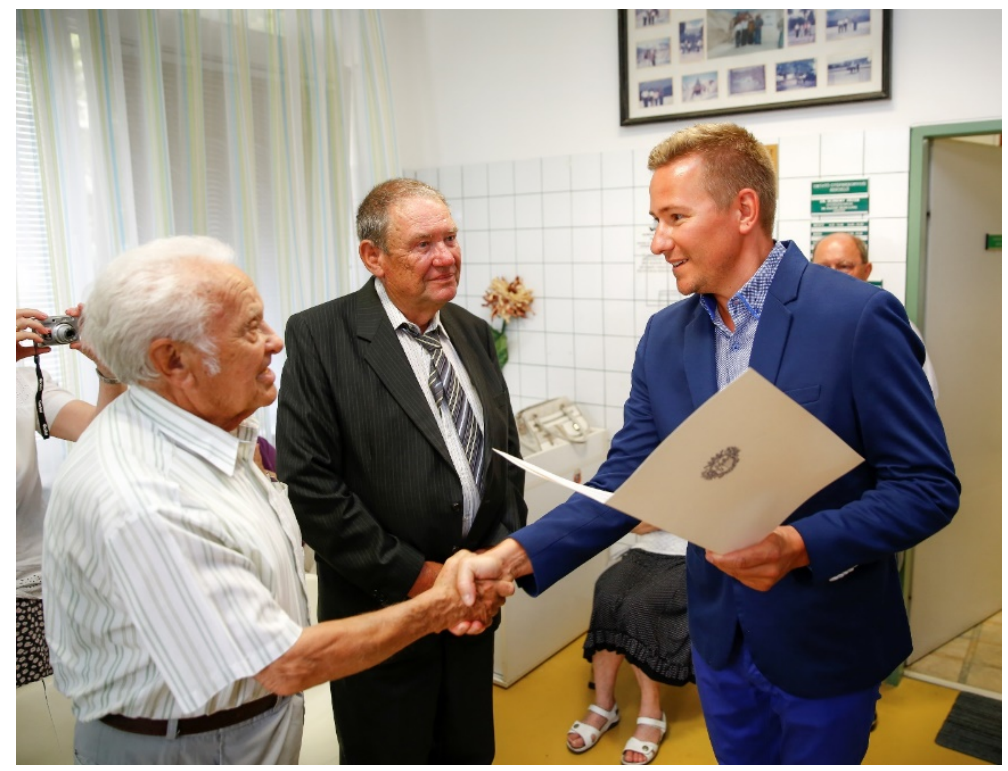

Forrás: Nagy István

2. ábra: Koszorúzás a Semmelweis Egyetem belső klinikai tömbjében, Prof. dr. Schmidt Péter, Prof. dr. Monos Emil, Prof. dr. Rosivall László (balról jobbra)

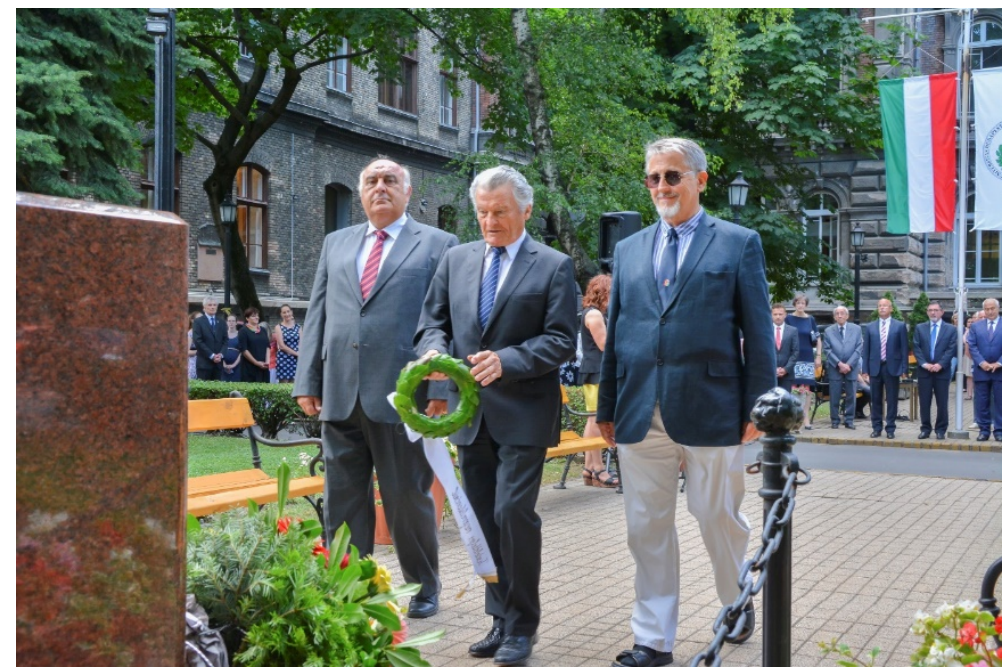

Forrás: Huszár Boglárka 
A 2017. évi győri rendezvényt követő napon a fővárosi központi Semmelweis ünnepségen Prof. Dr. Schmidt Péter együtt koszorúzott Dr. Monos Emil és Dr. Rosivall László professzorokkal a Semmelweis Egyetem Baráti Köre vezetősége képviseletében az
Üllői úti belső klinikai tömb udvarán található életnagyságú Semmelweis szobornál. ${ }^{4}$ A szobor felállításának kezdeményezésében Dr. Schmidt Péternek és néhai Fehér János professzornak is úttörő szerepe volt. ${ }^{1,4}$

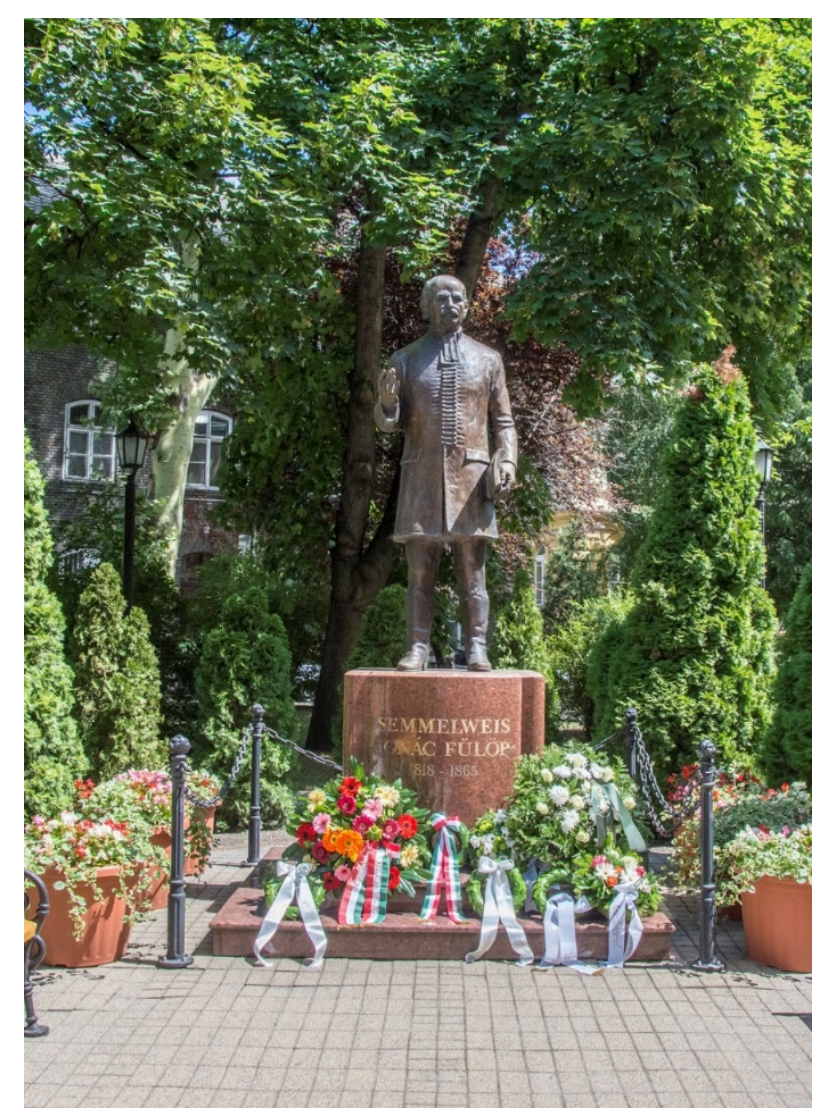

Forrás: Huszár Boglárka

\section{HIVATKOZÁSOK}

\footnotetext{
${ }_{1}$ Schmidt P. Forradalom és sorstragédia a szülészet történetében, Semmelweis élete és munkássága mai szemmel, ORVOSI HETILAP 144:(17) pp. 819-820. (2003)

2 Schmidt P. Kormos E. Korompáky M. Kitüntetések és elismerések a Semmelweis ünnepségen, EGÉSZSÉGFEJLESZTÉS 2009:(4) p. 15. (2009)

${ }^{3}$ Schmidt P. Semmelweis Ignác Fülöp tevékenységét a jövő nemzedék tudta csak igazán értékelni - a kiváló orvos-tudós munkásságának értékei a tudomány szemszögéből: Magyar Tudományos Akadémia Budapest, 2015. június 12. ORVOSI HETILAP 156:(51) pp. 2090-2092. (2015)

${ }^{4}$ Schmidt P. Molnár L. Donáth T. (szerk.) A Semmelweis Egyetem Baráti Körének első negyedszázada az egyetemért ORVOSI HETILAP 158:(14) pp. 559-560. (2017)

${ }^{5}$ Schmidt P. 190 éve született a világhírű orvos-tudós, EGÉSZSÉGFEJLESZTÉS 49:(5-6) p. 35. (2008)

${ }^{6}$ Schmidt P. Korompáky M. Semmelweis Ignác Fülöpre emlékeztek születése évfordulóján, EGÉSZSÉGNEVELÉS 46:(1-2) p. 18. (2005)
} 